\title{
Strategi pengelolaan kawasan Pantai Panjang sebagai wisata bahari di kota Bengkulu
}

\author{
Febriyanti $^{1}$, Mubarak $^{1}$, Hendrik $^{2}$ \\ ${ }^{1}$ Pascasarjana Ilmu Lingkungan Program Pascasarjana Universitas Riau \\ ${ }^{2}$ Fakultas Ferikananan dan Kelautan Universita Riau
}

*Correspondent email : architechantropus98@yahoo.com

\begin{abstract}
The coastal area of Bengkulu City's Long Beach currently has natural, cultural and historical tourism and forest tourism. However, tourism in Bengkulu City's Long Beach is still not optimal in its management. In addition to increasing the diversity of tourism in the Long Beach area of the city of Bengkulu, alternative tourism is needed, namely marine tourism in the city of Bengkulu. To support the management of Bengkulu City Long Beach tourism area as a marine tourism area, it is necessary to manage and develop Bengkulu City Long Beach area in accordance with the conditions and pay attention to the potential of natural resources around the area. This study aims to examine and analyze how the strategy of managing the Long Beach area of Bengkulu city becomes an integrated and sustainable marine tourism area.
\end{abstract}

Keywords: Coastal Zone; Management Strategy; Marine Tourism

Pariwisata bahari yang ada di Indonesia merupakan salah satu pariwisata yang sangat potensial untuk dikembangkan dan dikelola. Salah satu pariwisata yang mempunyai potensi cukup besar untuk dikembangkan menjadi tujuan wisata terletak di Provinsi Bengkulu. Provinsi Bengkulu secarageografisterletak di bagian Barat Pulau Sumatera. Wilayah bagian barat yang berbatasan dengan Samudera Hindia memiliki pantai yang panjangnya $\pm 525 \mathrm{~km}$ yang memanjang dari tenggara ke arah barat daya, mulai dari Kabupaten Kaur hingga Kabupaten Muko Muko.

Pengembangan dan pengelolaan kawasan pesisir menjadi tujuan wisata dengan konsep wisata bahari memberi dampak pada pembangunan kawasan pesisir yang dapat membuat perubahan pada lingkungan. Dampak yang timbul dari pembangunan kawasan pesisir untuk dikembangkan menjadi kawasan wisata dapat ditimbulkan dari adanya pemukiman penduduk, warung kecil, rumah makan, restauran dan penginapan disepanjang kawasan pesisir. Oleh sebab itu, maka diperlukan pengelolaan kawasan yang tepat dan menjaga kelestarian lingkungan yang ada dengan strategi dan partisipasi masyarakat setempat.

Pengembangan dan pengelolaan pariwisata suatu daerah sangat penting, karena dari sektor pariwisata ini salah satu penunjang pemasukan untuk Pendapatan Asli Daerah (PAD). Sehingga diperlukan peran pemerintah setempat yang bekerjasama dengan instansi terkait, pihak swasta dan masyarakat. Kebijakan pemerintah daerah pada sektor pariwisata ini sangat penting dalam keberhasilan memajukan pariwisata daerah.

Berdasarkan hal tersebut diatas, penelitian ini perlu dilakukan strategi pengelolaan kawasan pantai sebagai wisata bahari. Pengelolaan yang ada untuk saat ini tetap dengan mempertahankan dan tidak merusak lingkungan yang ada. Hanya saja pengelolaan kawasan pantai belum maksimal, sehingga masih terlihat belum tertata dengan rapi dan baik. Maka diharapkan untuk kedepannya dapat dilakukan kajian lebih lanjut untuk mencapai strategi pengelolaan kawasan pantai sebagai wisata bahari yang diharapkan tertata dengan baik

\section{METODE PENELITIAN}

Penelitian ini berlokasi di kawasan pantai kota Bengkulu. Penelitian ini dilaksanakan pada bulan Desember 2019.Dalam mengkaji pengembangan potensi kawasan tepi pantai sebagai wisata bahari, dilakukan metode survey dengan pendekatan deskriptif kualitatif yang disesuaikan dengan kondisi sosial, ekonomi, budaya dan adat istiadat setempat.Penelitian dengan metode deskriptif kualitatif yaitu satu metode penelitian yang digunakan dalam mengumpulkan informasi tentang keadaan yang sedang berlangsung pada saat itu dengan menggunakan pendekatan kualitatif.Tujuan dari metode ini adalah untuk menggambarkan suatu keadaan yang ada pada saat penelitian dilakukan dan memeriksa sebab akibat 


\section{ZONA}

Jurnal Lingkungan

ISSN : 2502-6496 (Print)

Volume 4, No 2, Oktober 2020, p. 60-66 http://zona.pelantarpress.co.id

melalui identifikasi dari gejala yang ada dari permasalahan. Metode ini dapat digunakan secara luas sehingga dapat membantu dalam melakukan indentifikasi atas variabel yang ada.

Informan didalam penelitian ini terdiri dari masyarakat pelaku usaha yang bertempat tinggal di sepanjang kawasan pantai sebanyak 30 orang. Dalam penelitian ini kasus yang diamati dilapangan lebih menitik beratkan pada usaha yang ada karena pelaku usaha salah satu faktor pendukung di dalam pengelolaan kawasan pantai sebagai tempat tujuan wisata dan juga meneliti pengelolaan kawasan pantai saat ini.

Penelitian dilakukan dengan wawancara dan penyebaran kuisioner kepada pelaku usaha, pengunjung dan narasumber. Hasil dari wawancara dan kuisioner dengan masyarakat, pelaku usaha dan juga narasumber terkaityang mengelola kawasan pantai saat ini akan dijadikan bahan acuan yang akan dikelola menjadi salah satu sumber data didalam pengelolaan kawasan pantai. Selanjutnya sampel juga dilakukan dengan penyebaran kuisioner, yang nantinya akan dilakukan penilaian terhadap hasil kuisioner. Subyek kasus dalam penelitian ini, yaitu pelaku usaha yang terdapat di kawasan pantai kota Bengkulu.

Data yang digunakan didalam penelitian ini akan menggunakan data primer dan data sekunder dan juga data yang diperoleh dari studi kepustakaan. Data Primer, yaitu data yang didapat secara langsung dilapangan yang diperoleh melalui objek penelitian, kuisioner dan observasi. Data tersebut diambil saat adanya event, promosi wisata dan brosur pada saat aktifitas pengunjung dan masyarakat yang berada di kawasan tepi pantai. Data sekunder yaitu data yang diperoleh melalui data yang telah diteliti dan dikumpulkan yang berkaitan dengan masalah penelitian untuk mengetahui permasalahan pengelolaan sumber daya alam, kependudukan, dan persepsi masyarakat disekitar pantai. Data sekunder yang diperoleh dari instansi terkait berupa data-data statistik, peta, laporan dan hasil kajian program-program pemerintah mengenai pengelolaan kawasan pantai. Data sekunder yang dikumpulkan juga dari studi pustaka, laporan hasil penelitian sebelumnya serta buku-buku yang terkait dengan penelitian ini. Studi kepustakaan yang telah dipublikasikan, wawancara, diskusi bersama pihak terkait, observasi yang dilakukan dengan cara pengambilan data melalui pengamatan langsung dilapangan.

Tabel 1. Data Primer dan Data Sekunder

\begin{tabular}{llll} 
No. & Jenis Data & Data Yang Digunakan & MetodePengumpulan \\
\hline \multirow{3}{*}{$1 \quad$ Data primer } & $\begin{array}{l}\text { Event, Promosi Wisata } \\
\text { dan brosur }\end{array}$ & \\
& Aktifitas Pengunjung & Wawancara, \\
& yang Berada di Kawasan & ObservasiLapangan \\
& Tepi Pantai & \\
& $\begin{array}{l}\text { Data-data statistik, peta, } \\
\text { laporan dan hasil kajian } \\
\text { program-program } \\
\text { pemerintah mengenai } \\
\text { pengelolaan kawasan } \\
\text { pantai }\end{array}$ & \\
& \multirow{3}{*}{ Data sekunder } & Lapangan & \\
& &
\end{tabular}

Penelitian ini dilakukan dengan pengumpulan data di lapangan dengan melakukan wawancara dengan masyarakat yang bertempat tinggal di kawasan pesisir Pantai Kota Bengkulu dan penyebaran kuisioner untuk mengetahui tanggapan responden terhadap pengembangankawasan pantai Kota Bengkulu, juga penyebaran kuisioner ke beberapa responden. Pengumpulan data di lapangan dilakukan dengan cara sebagai berikut :

1. Kuiosoner, penyebaran kuisioner di lapangan untuk melihat dan mengetahui seberapa jauh tanggapan para responden dalam pengembangan dan pengelolaan kawasan pantai menjadi kawasan wisata bahari.

2. Wawancara yang dilakukan kepada responden / masyarakat sekitar serta narasumber yang langsung berhubungan dengan pengelolaan kawasan pantai ini untuk mengetahui seberapa jauh kondisi kawasan pantai saat ini. Dengan demikian maka dapat diketahui bagaimana kondisi di lapangan yang ada.

Selain itu studi literatur juga membantu untuk melengkapi data - data yang diinginkan untuk penelitian di lapangan. 
Penelitian ini menggunakan analisis SWOT (Strengths, Weaknesses, Opportunities, and Threats) dimana fungsinya adalah untuk mempermudah dalam penelitian yang dapat memberikan gambaran tentang permasalahan yang perlu diindikasikan untuk keperluan tertentu, menganalisis hubungan antar permasalahan dan memberikan rancangan keadaan sekarang dan masa yang akan datang. Penjelasan dari setiap potensi yang ada dilakukan dengan analisis deskriptif kualitatif.

Analisis data yang akan digunakan adalahdengan menggunakan analisis SWOT (strengths (kekuatan), weaknesses (kelemahan), opportunities (peluang) dan threats (ancaman)). Analisis SWOT secara sederhana dipahami sebagai pengujian terhadap kekuatan dan kelemahan internal sebuah organisasi, serta kesempatan dan ancaman lingkungan eksternalnya. SWOT adalah perangkat umum yang didesain dan digunakan sebagai langkah awal dalam proses pembuatan keputusan dan sebagai perencanaan strategis dalam berbagai terapan, termasuk permasalahan pada strategi pengembangan pantai di kota Bengkulu sebagaiwisatabahari.Hasil kuisioner dan wawancara langsung di lapangan dengan responden dan beberapa narasumber akan menjadi elemen dalam SWOT.

Jika hal ini dilakukan maka dimungkinkan penelitian ini mendapatkan sebuah gambaran menyeluruh mengenai situasi pantai panjang kota Bengkulu untuk dijadikan sebagai salah satu wisata bahari yang ada di Indonesia. Sedangkan pemahaman mengenai faktor-faktor eksternal yang terdiri atas ancaman dan kesempatan, yang digabungkan dengan suatu pengujian mengenai faktor-faktor internal yakni kekuatan dan kelemahan akan membantu dalam mengembangkan sebuah visi masa depan.

Analisis SWOT dipengaruhi oleh 2 (dua) faktor, yaitu faktor internal dan faktor eksternal yang berasal dari kawasan pantai kota Bengkulu.Faktor internal merupakan faktor yang berasal dari dalam kawasan pantai itu sendiri,yangakan dipilah menjadi faktor-faktor yang bersifat memberi kekuatan dan faktor-faktor yang bersifat melemahkansedangkan faktor eksternal merupakan faktor yang berasal dari luar kawasan pantai dapat berasal dari masyarakat, dinas setempat dan lain-lain. Faktor-faktor yang bersumber dari eksternal akan dipilah menjadi faktor-faktor yang bersifat memberikan peluang dan faktor-faktor memberikan ancaman terhadap kegiatan yang dapat mempengaruhi kawasan pantai sebagai wisata bahari.

Makna dan pesan yang paling mendalam dari analisis SWOT adalah apapun cara- cara serta tindakan yang diambil, proses pembuatan keputusan harus mengandung dan mempunyai prinsip kembangkan kekuatan, minimalkan kelemahan, tangkap kesempatan, dan hilangkan ancaman. Terkait dengan penulisan tesis ini, data sebagai bahan analisis selain didapatkan dari dokumen-dokumen yang ada, didapatkan juga dari kegiatan survey berupa penyebaran kuesionerterkait dengan masalah umum, gedung, kemampuan teknis, sistem administrasi dan sumber daya manusia. Pertanyaan kuesioner tersebut mewakili komponen yang terdapat pada analisis SWOT, yakni strength (kekuatan), weakness (kelemahan), opportunities (peluang), dan threats(ancaman). Adapun masing-masing kategori (kekuatan, kelemahan, peluang dan ancaman) dituangkan dalam kuisoner pada lampiran 2.

Setelah seluruh faktor-faktor yang berpengaruh diperoleh maka tahap selanjutnya adalah pengolahan data.Jawaban dari kuisioner dikonversi ke dalam suatu nilai tertentu untuk mendapatkan penilaian totalitas yang dapat dilihat dalam matrik SWOT yang dapat dijadikan sebagai pegangan dalam kegiatan analisis. Dari masing-masing faktor internal dibandingkan dengan faktor eksternal untuk memperoleh strategi apa yang akan dilakukan dalam memecahkan masalah dari dua faktor yang dibandingkan tersebut. Berdasarkan dari matrik SWOT maka akan diperoleh minimal empat strategi yang akan digunakan untuk pencapaian tujuan. Namun demikian dari strategi yang yang diperoleh dari matrik SWOT dapat dilakukan pemilahan untuk menjadi strategi prioritas yang akan digunakan untuk pencapaian tujuan.

Analisis SWOT digunakan untuk mengetahui strategi apa yang akan digunakan setelahmelihat kekuatan, kelemahan, peluang dan ancaman untuk menjadikan kawasan Pantai Panjang Kota Bengkulu sebagai Wisata Bahari. Berikut ini langkah- langkah selanjutnya setelah diperoleh analisismengenai kekuatan, kelemahan, peluang dan ancaman pada pengembanganpantaipanjangkota Bengkulu sebagaiwisatabahari:

\section{Identifikasi faktor- faktor internal dan eksternal}

Identifikasi faktor- faktor internal dan eksternal ini diperoleh dengan memanfaatkan seluruh hasil analisis. Selanjutnya informasi yang diperoleh diklasifikasikan. Hal ini dilihat pada tabel berikut ini: 
Tabel 2. Analisis Faktor Internal dan Eksternal

\begin{tabular}{|c|c|c|c|}
\hline $\begin{array}{l}\text { Faktor - Faktor Startegi } \\
\text { Internal dan Eksternal }\end{array}$ & Bobot & Rating & Bobot $x$ Rating \\
\hline
\end{tabular}

Kekuatan

Kelemahan

Peluang

Ancaman

Sumber : Freddy Rangkuti, 2006

\section{Keterangan:}

Pemberian bobot masing- masing skala mulai 1,0 (paling penting) sampai 0,0 (paling tidak penting) berdasarkan pengaruhnya. Semua bobot tersebut tidakboleh melebihi skor total 1,00 . Pemberian rating untuk masing- masing faktor dengan skala mulai dari empat sampai dengan satu berdasarkan pengaruh faktor tersebut terhadap pengembangan kawasan pantai menjadi wisata bahari. Pemberian nilai rating untuk faktor kekuatan dan peluang yang bersifat positif semakin besar diberi rating 4 tetapi bila kecil diberi rating 1 . Pemberian nilai rating kelemahan dan ancaman yang bersifat negatif semakin besar diberi rating 1 tetapi bila kecil diberi rating 4 .

\section{Matrik Internal -Eksternal}

Total Skor Faktor Strategi Internal

Total skor faktor Strategi menengah eksternal

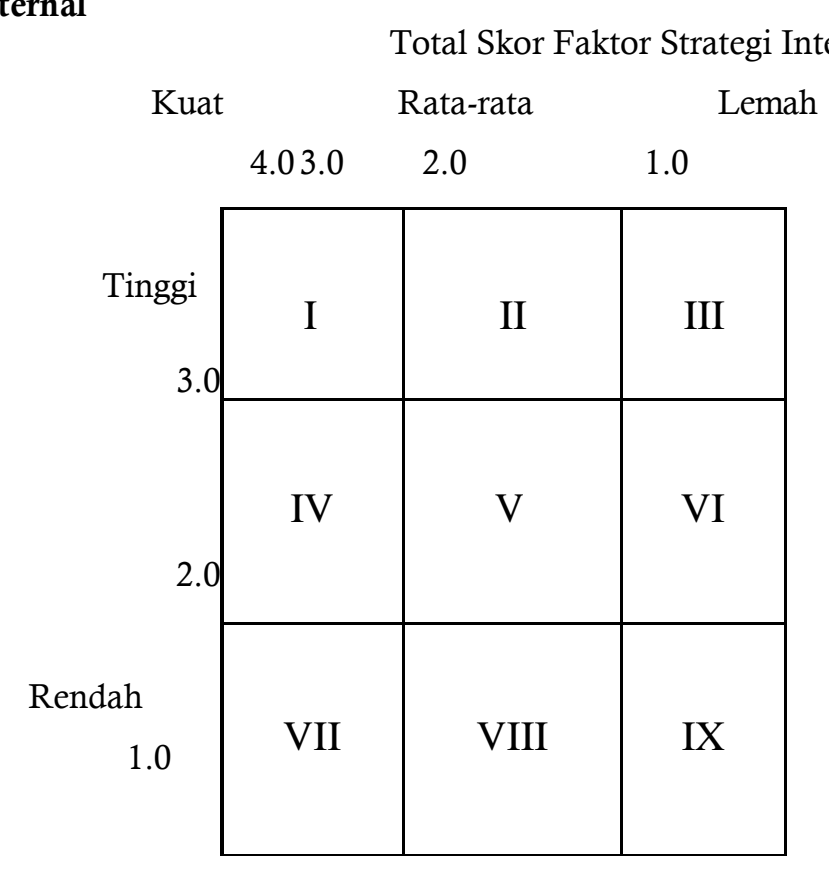

Keterangan :

I : Strategi konsentrasi melalui integrasi vertikal

II : Strategi konsentrasi melalui integrasihorisontal

III : Strategi turnaround

IV : Strategi stabilitas

$\mathrm{V}$ : Strategi konsentrasi melalui integrasi horisontal atau stabilitas

VI : Strategi divestasi

VII : Strategi diversifikasi

VIII : Strategi diversifikasi konsentrik

IX : Strategi likuiditas (tidakberkembang)

Sumber : Freddy Rangkuti(2006)

Setelah mengumpulkan informasi yang berpengaruh terhadap pengembangan kawasan pantai Kota Bengkulu menjadi wisata bahari, tahap selanjutnya adalah memanfaatkan informasi tersebut kedalam rumusan strategi. 


\section{ZONA}

Jurnal Lingkungan

ISSN : 2502-6496 (Print)

Volume 4, No 2, Oktober 2020, p. 60-66 http://zona.pelantarpress.co.id

Alat yang dipakai untuk menyusun strategi adalah matrik SWOT. Matrik ini menggambarkan secara jelas bagian peluang dan ancaman eksternal yang dihadapi disesuaikan dengan kekuatan dan kelemahan yang dimiliki. Matrik ini dapat menghasilkan 4 sel kemungkinan alternative strategi sebagai berikut:

Tabel 3. Matrik Analisis SWOT

\begin{tabular}{|c|l|l|}
\hline Eksternal & \multicolumn{1}{|c|}{ S } & \multicolumn{1}{c|}{ W } \\
\hline $\begin{array}{c}\text { Opportunities } \\
\text { (peluang) }\end{array}$ & $\begin{array}{l}\text { Strategi S-O ciptakan strategi } \\
\text { yang menggunakan kekuatan } \\
\text { untuk memanfatkan } \\
\text { peluang }\end{array}$ & $\begin{array}{l}\text { Strategi W-O ciptakan } \\
\text { strategi yang meminimalkan } \\
\text { kelemahan untuk } \\
\text { memanfaatkan peluang }\end{array}$ \\
\hline $\mathrm{T}$ & $\begin{array}{l}\text { Strategi S-T ciptakan strategi } \\
\text { yang menggunakan kekuatan } \\
\text { untuk mengatasi ancaman } \\
\text { Threats }\end{array}$ & $\begin{array}{l}\text { Strategi W-T ciptkana } \\
\text { strategi yang meminimalkan } \\
\text { kelemahan dan menghindari } \\
\text { ancaman }\end{array}$ \\
\hline
\end{tabular}

Sumber : Freddy Rangkuti (2006)

Keterangan :

1. Strengths (S): Kekuatan, yaitu faktor- faktor kekuatan yang dimiliki oleh pantai kota Bengkulu untuk dijadikan keunggulan dalam hal pengembangan kawasan pantai kota Bengkulu menjadi kawasan wisata bahari.

StrategiSO :

Apabila didalam kajian terlihat peluang- peluang yang tersedia ternyata juga memiliki posisi internal yang kuat, maka sektor tersebut juga memiliki posisi internal yang kuat, maka sektor tersebut dianggap memiliki keunggulan komparatif. Dua elemen eksternal dan internal yang baik ini tidak boleh dilepaskan begitu saja, tetapi akan menjadi hal penting dalam pengembangan kawasan pantai. Meskipun demikian proses pengkajiannya tidak boleh dilupakan adanya berbagai kendala dan ancaman perubahan. Kondisi lingkungan yang terdapat di sekitarnya dapat digunakan sebagai usaha dalam mempertahankan keunggulan dalam pengembangan kawasan pantai tersebut.

(Strategi SO : menggunakan kekuatan memanfaatkan peluang).

2. Weakness (W) : Kelemahan, yaitu keterbatasan atau kekurangan dalam hal sumber, keterampilan dan kemampuan yang menjadi penghalang serius bagi pengembangan kawasan pantai Kota Bengkulu menjadi wisata bahari.

Strategi WT

Merupakan tempat untuk menggali berbagai kelemahan yang akan dihadapi oleh sektor dalam perkembangannya. Hal ini dapat dilihat dari pertemuan antara ancaman dan tantangan dari luar dengan kelemahan yang terdapat didalam kawasan. Strategi yang harus ditempuh adalah mengambil keputusan untuk mengendalikan kerugian yang akan dialami dengan sedikit membenahi sumberdaya internal yang ada.

( Strategi WT : meminimalkan kelemahan dan mengusir hambatan).

3. Opportunity $(\mathrm{O})$ : Peluang, yaitu berbagai situasi lingkungan yang menguntungkan bagi pengembangan kawasan pantai Kota Bengkulu menjadi kawasan wisata bahari.

Strategi WO

Strategi WO merupakan kajian yang menuntut adanya kepastian dari berbagai peluang dan kekurangan yang ada. Peluang yang besar disini akan dihadapi oleh kurangnya kemampuan sektor untuk mengungkapnya. Pertumbuhan harus dilakukan dengan hati-hati untuk memilih dan untuk menerima peluang tersebut, khususnya dikaitkan dengan potensi kawasan.

( Strategi WO : menggunakan peluang untuk menghindari kelemahan).

4. Threats(T): Ancaman, faktor- faktor lingkungan yang tidak menguntungkan bagi pengembangan kawasan pantai Kota Bengkulu menjadikawasanwisatabahari.

Strategi ST

Strategi ini merupakan kajian yang mempertemukan interaksi antara ancaman atau tantangan dari luar yang diidentifikasikan untuk memperlunak ancaman atau tantangan tersebut, dan sedapat mungkin merubahnya menjadi sebuah peluang bagi pemberdayaan selanjutnya.

( Strategi ST : menggunakan kekuatan untuk mengusir hambatan). 


\section{HASIL DAN PEMBAHASAN}

Provinsi Bengkulu merupakan salah satu Provinsi di Indonesia yang terletak dipesisir pantai, dimana terdapat beberapa pantai yang terletak di kota dan kabupaten yang berada di Provinsi Bengkulu yang mempunyai potensi besar dan bagus untuk dikembangkan menjadi lokasi wisata bahari. Kota Bengkulu yang merupakan ibu kota Provinsi Bengkulu dengan luas151.7 km2memiliki pantai yang berpotensi untuk dijadikan tujuan pariwisata, dimana lokasi wisata tersebut terletak di Pantai Panjang.

SecarageografisKota Bengkuluterletak ditepi pantai Barat Pulau Sumatera beradadiantara 3045"3059"Lintang Selatan serta102022" BujurTimur. Secaraadministratif, Kota Bengkulu langsungberbatasandengan

3. Sebelah Utara

4. Sebelah Selatan

5. Sebelah Timur

6. Sebelah Barat
Kabupaten Bengkulu Utara
KabupatenSeluma
Kabupaten Bengkulu Selatan
: Samudera Indonesia.

Berdasarkan data darisensus penduduk yang dilakukan oleh Badan Pusat Statistik menunjukkan bahwa penduduk Kota Bengkuluberjumlah 376.50 Jiwa pada tahun 2018 yang tersebar di 9 Kecamatan.Adapun sebaranpenduduk menurut kecamatan dapat dilihat pada tabeldibawah ini :

Tabel 4. Jumlah Penduduk di Kota Bengkulu

\begin{tabular}{lcccc}
\hline \multirow{2}{*}{ Kecamatan } & \multicolumn{3}{c}{ Jumlah Penduduk Kota Bengkulu (Jiwa) } \\
\cline { 2 - 5 } Selebar & $\mathbf{2 0 1 7}$ & $\mathbf{2 0 1 8}$ & $\mathbf{2 0 1 7}$ & $\mathbf{2 0 1 8}$ \\
Kampung Melayu & 71.68 & 75.93 & 1.55 & 1.64 \\
Gading Cempaka & 41.48 & 43.57 & 1.79 & 1.88 \\
Ratu Agung & 44.17 & 44.71 & 3.06 & 3.10 \\
Ratu Samban & 50.75 & 50.73 & 4.61 & 4.60 \\
Singaran Pati & 25.37 & 25.36 & 8.93 & 8.93 \\
Teluk Segara & 42.07 & 42.25 & 2.91 & 2.93 \\
Sungai Serut & 23.32 & 23.11 & 8.45 & 8.37 \\
Muara Bangkahulu & 23.99 & 24.18 & 1.77 & 1.79 \\
Kota Bengkulu & 45.25 & 46.65 & 1.95 & 2.01 \\
& 368.10 & 376.50 & 2.43 & 2.48 \\
\hline
\end{tabular}

Sumber : BPS Kota Bengkulu, 2018

Kota Bengkulu yang merupakan salah satu daerah yang terletak di daerah pesisir, saat ini memiliki beberapa tempat pariwisata. Wisata yang dimiliki saat ini antara lain :

1. Wisata Alam

Wisata alam yang ada di kota Bengkulu saat ini yaitu, Pantai Panjang, Pantai Pasir Putih, Pantai Tapak Paderi dan Pantai Zakat. Selain itu kota Bengkulu juga memiliki wisata alam Pulau Tikus dan Danau Dendam Tak Sudah.

2. Wisata Budaya dan Peninggalan Sejarah

Kota Bengkulu memiliki warisan budaya dari masa lampau yang saat ini dilestarikan dan dijadikan objek wisata bagi wisatawan yang berkunjung, diantaranya ada Benteng fort Malborough yang terletak di kawasan Pantai Panjang, Rumah Pengasingan Bung Karno dimana rumah ini berisi peninggalan dari Bung Karno dan beberapa sejarah yang sangat berharga, Rumah Fatmawati, Parr and Hamilton Bengkulu, Museum Provinsi Bengkulu dan Makam Sentot Alibasyah.

3. Hutan

Selain wisata alam dan wisata budaya dan peninggalan sejarah, kota Bengkulu memiliki hutan yang dapat dijadikan objek wisata. Berbagai macam kekayaan hutan yang dapat ditemukan di Bengkulu seperti Bunga Rafflesia Arnoldi, Anggrek Air vanda Hookeriana, Kayu Medang, Meranti, Ratan dan Damar. Tanaman lainnya sangat dibudidayakan oleh masyarkat adalah Minyak Kelapa Sawit, Getah Karet, Kopi, Durian, Jeruk, Sayuran dan lainnya.

Letak pantai Panjang kota Bengkulu yang cukup strategis, dimana letak pantai ini berada pada kecamatan Ratu Agung, kecamatan Teluk Segara dan kecamatan Ratu Samban ini, menjadi salah satu daya tarik untuk pengembangan pariwisata di kota Bengkulu. 
Untuk mengetahui karakteristik responden pada Pantai Panjang kota Bengkulu, diperlukan survey, penyebaran kuisoner dan wawancara pada masyakarat sekita Pantai Panjang. Item pertanyaan diuji cobakan kepada 30 responden dengan jumlah 20 butir soal, dan hasil perhitungan validitas dan realiabilitas dinyatakan valid jika rhitung $\geq$ rtabel yaitu 0,514 . Hasil analisis uji validitas angket dapat dilihat pada lampiran 3.

Berdasarkan rumus, maka hasil perhitungan realibilitas angket dapat diperoleh r11 sebesar 0,942. Hasil perhitungan rhitung sebesar 0,942 dengan $\mathrm{n}=21$ ternyata lebih besar dari rtabel sebesar 0,514, maka dapat disimpulkan bahwa angket penelitian reliabel dan dapat digunakan untuk penelitian

Data yang didapat dari wawancara dan penyebaran kuisioner akan diberi penilaian persentase dan akan disusun didalam suatu tabel, sehingga akan didapatkan data yang diinginkan didalam penelitian terhadap pengelolaan dan pengembangan penataan kawasan tepipantai. Didalam penyusunan hasil wawancara dan kuisioneryang telah diuji validitas datanya, harus diperhatikan kevalidan data yang telah dikumpulkan. Uji validitas ini dilakukan sebelum penelitian dilakukan.

\section{KESIMPULAN}

Berdasarkan hasil penelitian yang telah dilakukan maka dapat diambil kesimpulan bahwa strategi pengelolaan wisata bahari dengan melihat kekuatan, kelemahan, peluang dan ancaman yang ada, dapat menjadi acuan didalam pengelolaan kawasan pantai menjadi wisata bahari dengan mengembangkan potensi wisata yang ada untuk menarik minat wisatawan untuk berkunjung dan juga mengenalkan pariwisata yang dimiliki oleh kota Bengkulu.

Dengan strategi yang dianalisa, maka salah satu daya tarik didalam wisata bahari yang dimiliki di kawasan pantai kota Bengkulu ini adalah lingkungan alami pantai dimana ekosistem pantai dan keanekaragaman laut yang dipunyai masih terbilang indah dan terjaga yang menjadi salah satu nilai jual pariwisata bahari. Selain itu fasilitas sarana dan prasarana yang ada harus lebih diperhatikan lebih lanjut sebagai salah satu penunjang obyek wisata yang ada. Dan juga hal yang dicari oleh wisatawan / pengunjung pada wisata bahari adalah wisata kuliner laut yang menjadi salah satu pelengkap didalam wisata bahari

\section{UCAPAN TERIMA KASIH}

Ucapan terima kasih penulis sampaikan kepada semua pihak yang telah membantu terlaksananya penelitian ini di lapangan.

\section{DAFTAR PUSTAKA}

Rangkuti, Freedy. 2002. Analisis SWOT Teknik Membedah Kasus Bisnis. Gramedia Pustaka Utama,; Jakarta

https://bengkulukota.bps.go.id/pressrelease.html yang diakses pada tanggal 09 Juli 2020 